\title{
sciendo
}

\section{IMAGINE THE UTOPIA! RETHINKING ALAIN BADIOU'S THEATRE-POLITICS ISOMORPHISM}

\author{
JAN MOTAL \\ Theatre Faculty, Janáček Academy of Music and Performing Arts in Brno
}

\begin{abstract}
The presented article is a polemic with Alain Badiou's concept of theatre-politics isomorphism. The author adapts the basic elements of Badiou's philosophy (event, void $\varnothing$, truth etc.), provides an interpretation of his theory of theatre and presents crucial critical arguments to reveal the reductionism of Badiou's philosophy. Subsequently, the author presents his alternative theory of theatre based on this ground. The article assumes that theatre performance is a live, truthful event, an encounter of humans experiencing an imagined Utopia based on their structural homology (shared materiality, phylogenetic archetypal memory, existentiality). The argument is supported by the recent research in neuroscience.

As the article argues, this Utopia has its social and political significance. The theatre is not political only if it constructs both a political body (crowd, public) and a discourse, as Badiou suggests. The author concludes that theatre is inherently political because its imaginative nature, which allows humans to experience the utopical attachment exceeding the subject-object boundaries. This imagined Utopia with its critical and anticipative power allows people to transcend their singularity to interpersonal and intercultural dialogue and universality, and it provokes their political imagination (in the sense of David Graeber). The author employs Erika Fischer-Lichte's concept of performativity to present theatre performance as an event.

Key words: theatre, liveness, dialogue, utopia, politics, event, universality, materiality, feedback loop
\end{abstract}

\section{Introduction}

In theatre studies and theatre criticism, to say that a theatre performance is political usually means that the piece is committed to a specific political ideology (mostly socialism). A presentation of the performance has to be political. ${ }^{1}$ This mindset has appeared in the late 1920s and 1930s, not only in the Continental Europe (Bertolt Brecht, Erwin Piscator) but also in the North America. The "political" in those cases

${ }^{1}$ Political theatre "[...] is a performance that is intentionally concerned with government, that is intentionally engaged in or consciously takes sides in politics [...]. If a theatre piece is intended to be political and the intent is not perceived, there is no need to categorize it as 'political theatre."' KIRBY, Michael. On Political Theatre. In The Drama Review, 1975, Vol. 19, No. 2, p. 129. See also BENTLEY, Eric. The Political Theatre Reconsidered. In The Kenyon Review, 1961, Vol. 23, No. 1, pp. 75 - 90; or KOBIALKA, Michal. Tadeusz Kantor and Hamed Taheri: Of Political Theatre/Performance. In The Drama Review, 2009, Vol. 53, No. 4, 2009, pp. 78 -91. For the claim on socialism see e.g. the study of 1990s British political theatre metamorphosis in SAKELLARIDOU, Elizabeth. Aporia or Euphoria: British Political Theatre at the Dawn of the 90s. In AAA: Arbeiten aus Anglistik und Amerikanistik, 1992, Vol. 17, No. 1, pp. 51 - 70. 
was a display of anti-fascist stance. ${ }^{2}$ It is therefore hardly surprising that the term is coined in genuinely modernistic fashion up to the present day. On the top of it, this approach supports the false belief that there can be a theatre which is not political, being purely aesthetical or entertaining, usually bourgeois. However, even in the bourgeois theatre people are taking part in building of community, although this effort is limited and it can be even antagonistic. The principal axiom of this essay is that the essential aim of politics is to establish a community ${ }^{3}$ - the Utopia of a universal community (engaging all the humans, animals and things ${ }^{4}$ ) being its ultimate horizon. This article does not aim to discuss the theory of political theatre as a genre. The goal of the polemic is to show that every theatre performance is political per se. I would like to propose that the horizon of "the political" in theatre is necessarily the Utopia, an anticipatory and prospective horizon, which has its imaginative power.

I am to employ Alain Badiou's theory of theatre as the starting point. The reasons are several: firstly, Badiou is a very popular philosopher among the contemporary artists, and he is a playwright. His theory also aspires to be radical. I am to show that this aspiration is not adequate. Badiou's model of theatre-politics isomorphism is regressive and leaves out the power of imagination, which is the condition sine qua non of every transgression. I would like to demonstrate that despite of his theory's problems in the core of Badiou's philosophy a very inspirative seed is enshrined. This seed can nourish the value of theatre. To achieve this, it is necessary to abandon the mathematical base of the Badiousian theory and reveal its existential ethos.

\section{The Politics-Theatre Isomorphism and Its Lack of Imagination}

Alain Badiou defines theatre in a threefold relation - to the state, morality and to the public (a spectator). The politics-theatre isomorphism is grounded on the situation of crowd construction and spectator's ability to be involved in a (political) discourse:

"Let's posit that there is theatre as soon as we can enumerate: first, a public gathered with the intent of a spectacle; second, actors who are physically present, with their voices and bodies, in a space reserved for them with the express purpose of the gathered public's consideration; and, third, a referent, textual or traditional, of which the spectacle can be said to be the representation." ${ }^{5}$

The equivalent a priori conditions of politics are massive event (the State), organizations (leaders), text-thoughts (discourse). Based on this transcendental assumption,

\footnotetext{
${ }^{2}$ ROBINSON, T. C. Fascism and the Political Theatre. In The Sewanee Review, 1936, Vol. 44, No. 1, pp. 53 67. It seems to be time for scholars to get rid of this pro-socialist sentiment and to study the other forms of it, e.g. fascist theatre, as well. Beyond that, it could be challenging for theatre history to confront the avant-garde's interest in ritual with the fascist use of it in performances. See e.g. BERGHAUS, Günter (ed.). Fascism and Theatre: Comparative Studies on the Aesthetics and Politics of Performance in Europe, 1925 - 1945. Berghahn Books, 1996. ISBN 978-1-78533-047-6.

${ }^{3}$ SLOTERDIJK, Peter. Im selben Boot: Versuch über die Hyperpolitik. Berlin : Suhrkamp, 1995. ISBN 978-3518-38947-8.

${ }^{4}$ I am committed to Bruno Latour's term of the world as a collective of human and non-human actors. See LATOUR, Bruno. Facing Gaia: Eight Lectures on the New Climatic Regime. Cambridge : Polity Press, 2017. ISBN 978-0-745-68433-8.

${ }^{5}$ BADIOU, Alain. Rhapsody for the Theatre: A Short Philosophical Treatise. In Theatre Survey, 2008, Vol. 49, No. 2, p. 190.
} 
Badiou postulates: "Theatre is the figurative reknotting of politics, and this regardless of its subject matter." ${ }^{\prime}$

It is noteworthy, that this theory relies on the classical definition of theatre as a text-based spectacle. Badiou employs the elements of dramatic theatre and ignores not only all the avant-garde and progressive forms (e.g. Antonin Artaud's Theatre of Cruelty, Richard Schechner's performances, and others) but he even leaves out mime, dance and pure, unrepeatable improvisation. For him, these all are nothing more than "theatrical exercises or ingredients"7. This position is similar to Klaus Lazarowicz's triadic collusion (performance is the result of an interplay between author, actor, and audience). ${ }^{8}$ It is surprising that such a progressive philosopher relies on the highly conservative view of theatre. But there is a simple explanation at hand.

Badiou's philosophy is Platonic - it proposes categorial assumptions. Badiou does not involve inductive arguments based on an analysis of theatre hic et nunc. His arguments are constructed on the pure deductions, grounded on highly modernistic (i.e. classical, not in the sense of modern avant-gardes) presumptions. This "Platonism" serves as a part of his philosophical program, which aims to give a new breath to ontology.

His criticism of post-modern cynicism ${ }^{9}$ leads to the vision of a common philosophical ground, which can be postulated only a priori. For Badiou, politics and art are specific truth-procedures (such as love and science) aiming to provide the universally plausible testimony. Therefore, politics is first of all discoursive, and it is isomorphic to the theatre's faculty of constructing crowds (the public) capable of forming a political body. ${ }^{10}$ This theory can be criticised from several viewpoints. I would like to mention only two of them, which I see as crucial for the following argument.

Firstly, Badiou adapts the thin definition of politics akin to the conservative stance, i.e. that politics occurs when a group of people with divergent opinions reaches collective decisions. ${ }^{11}$ I call this definition "thin" because it views politics only as a discoursive practice in the context of modern (national) state. Yet, in the Middle Ages or dictatorships ordinary people were not involved in such politics because the decisions were made only by a narrow circle of elite. And analogously, in contemporary democracies citizens experience the democratic deficit, meaning that "[...] in many countries today, satisfaction with the performance of democracy diverges from pub-

${ }^{6}$ Ibid., p. 193 .

${ }^{7}$ Ibid., p. 190.

${ }^{8}$ LAZAROWICZ, Klaus. Triadische Kollusion: Über die Beziehungen zwischen Author, Schauspieler und Zuschauer im Theater. In Das Theater und sein Publikum. Wien : Veröffentlichungen des Instituts für Publikumforschung, 1977, pp. 44 - 60. ISBN 3-7001-0238-0.

${ }^{9}$ Badiou's theatre theory consciously struggles with postmodernism, i.e. "[...] a period of apparent barbarism, of intrinsic valorization of the complexities of disorder, of the rejection of repetition and easily discernible configurations," as it is apparent e.g. in non-figurative painting or atonal music. BADIOU, Alain. Being and Event. London - New York : Bloomsbury Academic, 2015, p. 307. ISBN 978-1-472-51106-5.

${ }^{10}$ Badiou calls his theory of art "inaesthetics" and he distinguishes it from the established ways "of configuring the relation of art to philosophy": didactic (art as an imitation), romantic ("art alone is capable of truth"), classical (art is incapable of truth and even of truth's imitation). "Badiou [...] seeks to isolate the precise conceptual consequences of an encounter with art." See HALLWARD, Peter. Badiou: A Subject to Truth. Minneapolis - London : University of Minnesota Press, 2003, p. 194. ISBN 0-8166-3461-0.

${ }^{11}$ S. v. "politics" in MILLER, David et al. The Blackwell Encyclopaedia of Political Thought. Oxford - New York : Blackwell, 2008. ISBN 978-0-631-22781-6. 
lic aspirations." 12 Even today the political decisions are not performed by crowds. In fact, it is far from the truth to say that they have been performed in this fashion anytime in history.

If Alain Badiou's view of politics aims to engage people in the (discoursive) decision-making process, it is hardly plausible to do it in this conservative, Habbermasian modernistic way. As Michel Foucault shows in his work, the problem of politics can hardly be limited to the question of sovereignty (the State). The founding fathers of modernity proposed this model in the 16th and 17th centuries when the idea of modern (and later national) state was forming. Still, Foucault claims:

"Between every point of a social body, between a man and a woman, between the members of a family, between a master and his pupil, between every one who knows and every one who does not, there exist relations of power which are not purely and simply a projection of the sovereign's great power over the individual; they are rather the concrete, changing soil in which the sovereign's power is grounded, the conditions which make it possible for it to function."13

Politics is hardly merely discoursive - it is embodied in the daily interactions of humans. The particular social actors form a political body not only by their decisions or by forming parties and party-like subjects (movements et cetera), but they also use politics in their everydayness by the way they live. If theatre is isomorphic to politics, it has to engage the whole human body, not only language. Therefore, it is not a priori evident that without text there is no theatre, as Alain Badiou claims.

The next critical argument focuses on the omittance of the question of imagination. Badiou's definition of politics is a technocratic one. Moreover, was it not the relying on the technology of power, why has the project of modernistic state failed in the $20^{\text {th }}$ century in the epic tragedies, such as the Holocaust, the Holodomor (Soviet famine in Ukraine 1932 - 1933), or Pol Pot's rural terror of the Khmer Rouge?

As anthropologist David Graeber explains, "[...] all forms of systemic violence are (among other things) assaults on the role of imagination as a political principle, and the only way to begin to think about eliminating systematic violence is by recognizing this." ${ }^{14}$ The Stalinists or Maoists did not kill because of their utopical dreams, but because they were short on imagination, proposing their politics as a kind of science. For them, the future was a certainty, not a possibility.

Graeber's political theory sees states as having a dual character: "They are at the same time forms of institutionalized raiding or extortion, and utopian projects."15 This imaginary totality is based on (a false) presumption, that a state is an idea, "[...] way of imagining social order as something one could get a grip on, models of control." The proper socio-political critique has to be based on a theory of the relation of violence and the imagination, leading to the ultimate question: "[...] what, precisely, are the possible dimensions of non-alienated experience?"16 These dimensions of

${ }^{12}$ NORRIS, Pippa. Democratic Deficit: Critical Citizens Revisited. Cambridge : Cambridge University Press, 2011, p. 4. ISBN 978-0-521-12744-8.

${ }_{13}^{13}$ FOUCAULT, Michel. Power/Knowledge: Selected Interviews and Other Writings 1972-1977. New York : Pantheon Books, p. 187. ISBN 0-394-51357-6.

${ }^{14}$ GRAEBER, David. Fragments of an Anarchist Anthropology. Chicago : Prickly Paradigm Press, 2004, p. 11. ISBN 0-9728196-4-9.

${ }^{15}$ Ibid., p. 65.

${ }^{16}$ Ibid., pp. 73, 75. 
the least alienation are present in our everydayness, they are not technocratic ideals a priori, but lived possibilities. ${ }^{17}$ The true utopianism leads not to totality, but it aims to provoke practical imagination and to enrich people's practical ability to live out of alienation.

\section{The Event and Its Dehumanized Truth}

The core element of Badiou's philosophical project is the concept of an event. An event is a point of situation, which "[...] 'concerns' a multiple presented in situation [...]". Natural or neutral situations cannot be events, they are facts. Any event has its (historical) place. ${ }^{18}$ For more precise definition Badiou employs mathematical symbols and presents the matheme of the event in his Meditation 17:

$$
(*) e_{x}=\left\{x \in X, e_{x}\right\}
$$

This is equivalent to the non-formal definition: "I term event of the site $\mathrm{X}$ a multiple such that it is composed of, on the one hand, elements of the site, and on the other hand, itself." ${ }^{19}$ What Badiou calls "event" is the edge of the void (i.e. of an empty set, $\varnothing):^{20}$

"[T]he liminal space between representation and presentation; it hovers between immanence and transcendence, composed on the one hand entirely by the elements of its site, yet on the other hand constituting a brand-new configuration that cannot be thought within the situation." 21

An event presents the limit of situation and displays being-as-being which is lost under "the state of the situation" (ideology) with all of its multiplicity. All the possibilities are at our hands, and if we can recognize subjectivity in others and address them the truth of the event, hope becomes universal (such as the universally addressed truth). Therefore, truth is post-eventutal. It arises from the event and, being an indiscernible multiple, it can hardly be fully articulated, only lived by the subject which it constitutes. ${ }^{22}$

Alain Badiou's philosophy springs from his political beliefs based on particular historical experience. It was the "five intense years" 1962 - 1968 in France, "between the end of the war in Algeria and the revolutionary storm of the period $1968-1976$ ",

${ }^{17}$ A that is why art, theatre and politics "permeated everyday life" during the 1960s - blurring the frontiers of theatre ("Were civil rights activists who sang freedom songs as part of the civil rights movement performers in the same way as, say, the avant-garde theater company the Living Theatre [...]"?) and paving the way for "the performative turn". But even in those excited times, the politics in performances was intentional and perceptibly expressed. See MARTIN, Bradford D. The Theater Is in the Street: Politics and Performance in Sixties America. Amherst - Boston : University of Massachusetts Press, 2004, p. 4. ISBN 1-55849-449-9.

${ }^{18}$ BADIOU, Alain. Being and Event..., p. 187.

${ }^{19}$ Ibid., p. 188.

20 "Viewed from the perspective of the state of situation, the inconsistent multitude - pre-symbolic being, or being-as-being - appears as nothing." BELL, Lucy. Articulations of the Real: from Lacan to Badiou. In Paragraph, 2011, Vol. 34, No. 1, 2011, pp. $106-107$.

${ }^{21}$ BADIOU, Alain. Being and Event..., p. 110.

${ }^{22}$ Ibid., p. 433. 
which his generation counts as the key philosophical moment of their lives. ${ }^{23}$ In Badiou's texts, we can clearly identify a vivid interest in revolutionary theory.

No doubt Badiousian event is pretty much like Hegelian historical break. "History is the process whereby the spirit discovers itself and its own concept," says Hegel in Lectures on the Philosophy of World History. ${ }^{24}$ Likewise Badiou assumes that an event "[...] can only be revealed in the retroaction of an interventional practice which is itself entirely thought through." ${ }^{25}$ To conceptualize the event is of the constitutive importance for a subject.

The subject's fidelity to the truth of the event reveals the event itself and forms a commitment - the subject is from this moment a militant. In Hegelian terms, the evolution of human freedom happens through "world-historical events" (this is the base of Marxist revolutionary materialism). Although Badiou does not write history of this emancipation, he focuses on an ontology of these events to show how they produce truth and subject. Badiousian subject is "[...] any local configuration of a generic procedure from which a truth is supported," ${ }^{26}$ a local status of a procedure. Not a bodily human.

Any Badiousian event is a historical situation, which can be formalized:

$$
(* *) \alpha \cap \beta=\varnothing
$$

This equation has to be understood as the ontological schema of a historical situation, which is "[...] a multiple such that there belongs to it at least one multiple $[\beta]$ whose intersection with the initial multiple $[\alpha]$ is void [...]." ${ }^{27}$ Any subject in the historical situation recognizes, that there is an edge-of-the-void, that there is "nothing" with which the subject is confronted, but this nothingness is prospective, it is a being as being, multiplicity, i.e. freedom. The fidelity to this event produces specific truth with its universal appeal.

This is also Badiou's general law of ontology, "the axiom of foundation" proposed in his Meditation 18. It poses that every "non-void multiple contains some Other":

$$
\left({ }^{* * *}\right)(\forall \alpha)[(\alpha \neq \varnothing) \rightarrow(\exists \beta)[(\beta \in \alpha) \&(\beta \cap \alpha=\varnothing)]]
$$

This axiom states that "[...] even though presentation can be infinite [...] it is always marked by finitude when it comes to its origin. Here, this finitude is the existence of a site. On the edge of the void; historicity." 28

For Badiou, theatre cannot produce transforming events per se - if there is no crowd, no public, no people and no discourse on the historical situation (an event revealed in conceptual retroaction), there is no politics and no truth. This is why Ba-

${ }^{23}$ PAWLING, Christopher. Reviving the Critical Spirit of May '68: Alain Badiou and the Cultural Politics of the ,Event'. In Critical Theory and Political Engagement. London : Palgrave Macmilan, 2013, p. 88. ISBN 978-1-349-32497-2.

${ }^{24}$ HEGEL, Georg Wilhelm Friedrich Hegel. Lectures on the Philosophy of World History: Introduction. Cambridge : Cambridge University Press, 1980, p. 62.

${ }^{25}$ BADIOU, Alain. Being and Event..., p. 187.

${ }^{26}$ Ibid., p. 411.

${ }^{27}$ Ibid., p. 194.

${ }^{28}$ Ibid., p. 196. 
diou so heavily relies on the discoursive essence of theatre. So that is why he misses all the possibilities of imagination in performance. The imagination is relevant only as the historical testimony.

\section{The Critique of Alain Badiou}

One of the most important polemics on Badiou's theory has taken place on the pages of Critical Inquiry (volumes 37 and 38) recently. It had been started in an arti$\mathrm{cle}^{29}$ written by father and son, scholars Ricardo (who is a mathematician) and David (a professor of social thought and medieval history) Nirenberg. Their critique can be summarised in these three theses: ${ }^{30}$

"[...] Badiou's set-theoretical model for ontology are at best a priori commitments rather than necessary truths of the set theory within which they are made."

"[...] Badiou confuses contingent attributes of informal models with necessary consequences of the axioms [...]." ("A Pythagoric snare")

"The politico-philosophical claims that result have no grounding in the set theory that is developed to justify them."

The polemics in Critical Inquiry revealed that Badiou employs symbols and theorems of mathematics to utilize them as a creative material, but not as any axiomatic ground he claims they should be. Therefore, to prevent the dehumanizing reductionism, I would like to uncouple Badiou's theory from mathematics.

Let us start from the critique of the event matheme and its founding on the claim of infinity $\left(\left(^{*}\right)\right.$ and $\left.\left({ }^{* * *}\right)\right)$. Nirenbergs oppose aforementioned Badiou's conclusions as follows:

"From a mathematical point of view even the sum of all the facts, traces, gestures, ideas, and dreams of human history is finite rather than infinite. [...] Certainly the world is complex, far too complex to be captured in its entirety by historical or any other human tools. But to call French Revolution or any other politico-historical event an ,infinite multiple' is to deliberately obscure the basic ontological differences that made the modern discovery of infinity such a revolutionary event in human thought." 31

In a mathematical sense, there is no "infinity" (no void) in history. But we can see these historical situations as singularities of possibilities, i.e. as manifestations of human freedom. If we abandon the set theory, we can perceive the existential ground of Badiou's philosophy. ${ }^{32}$ The void is then a free space of human will in the nearly

${ }^{29}$ NIRENBERG, Ricardo L. - NIRENBERG, David. Badiou's Number: A Critique of Mathematics as Ontology. In Critical Inquiry, 2011, Vol. 37, No. 4, pp. 583 - 614. See also Badiou's response (BADIOU, Alain - BARTLETT, A. J. - CLEMENS, Justin. To Preface the Response to "Criticisms" of Ricardo Nirenberg and David Nirenberg. In Critical Inquiry, 2012, Vol. 38, No. 2, pp. 362 - 364) and following reply to Badiou and his defenders (NIRENBERG, Ricardo L. - NIRENBERG, David. Reply to Badiou, Bartlett, and Clemens. In Critical Inquiry 2012, Vol. 38, No. 2, pp. 381 - 387).

${ }^{30}$ Ibid., pp. $585-586$.

${ }^{31}$ Ibid., p. 598.

${ }^{32}$ Thus it is true what Roger Scruton claims (even if he says it as a rebuke): "It gradually becomes clear, through the haze of mathemes and nonsemes, that Badiou is rewriting - or rather over-writing - the Sartrean philosophy of commitment. He is telling us that we become free subjects through intervening in the course of things, so as to commit ourselves to the great Event." SCRUTON, Roger. Fools, Frauds and Firebrands: Thinkers of the New Left. London - New York : Bloomsbury, 2015, p. 251. ISBN 978-1-4081-8733-3. 
Nietzschean sense. The subject involved in an event is located on the edge of an abyss, which has both positive and negative appearance. The former is tragic, the latter prospective - it is both the threatening Nietzschean "Abgrund" and "the freedom of great souls", independent and self-determining. ${ }^{33}$ This dangerous freedom is the nothingness, which at the same time is the ultimate possibility of the creative human. Without metaphysics (Badiou's count-as-one) and pessimism (Badiou's cynicism) the subject on the edge of the void experiences both mortality and freedom. Nietzsche says:

"[...] one could conceive of such a pleasure and power of self-determination, such a freedom of the will that the spirit would take leave of all faith and every wish for certainty, being practiced in maintaining himself on insubstantial robes and possibilities and dancing even near abysses. Such a spirit would be the free spirit par excellence." 34

The edge of the void can not be experienced by a mere abstract subject. In abstraction there is no experience, which is only particular. The edge is the very point, where any philosophical demand on a human is exposed as infeasible (and maybe this is the reason, why Nietzsche employed the instruments of poetry in his work). It is a real, empirical, living human, who can look into the abyss and see both its horror and promise.

It is, therefore, desirable to "[...] deprive philosophy of its transcendental claim over the Real [...],"35 as François Laruelle proposes. In his project of non-philosophy "[...] Laruelle attempts to identify an ordinary man as a radically finite, immanent individual, irreducible in his multiplicity and irreplaceable in his singularity." His effort is based on the assumption that "philosophy tries to couple man to its universals" and therefore it "conflates the lived experience of the ordinary man with the universalized and abstract category of being." 36

Laruelle's polemic with Badiou is more extensive, ${ }^{37}$ but it can be summarized in the metaphor of "introducing Maoism into philosophy". What Badiou does is that he aims to tighten the screws on Real in terms of philosophy. This "cultural revolution" chases ordinary human in the name of mathematics, instead of admitting its particularity. But philosophy is not a priori of a human life, there is no existence or being prior to human, and what more - we can barely have any knowledge on him. ${ }^{38}$

\section{Towards the Mystery}

As Gabriel Marcel testifies, the Real is "mystery, intelligible solely as mystery. This also applies to myself." 39 Philosophy tries to "have" human, to grasp him and govern him (by knowledge) - corporeity (so much dismissed by Badiou, so much

${ }^{33}$ NIETZSCHE, Friedrich. The Gay Science. New York : Vintage Books, 1974, p. 150 (§98). ISBN 0-39471985-9.

${ }^{34}$ Ibid., pp. 289 - $290(\$ 347)$.

${ }^{35}$ LARUELLE, François. Principles of Non-Philosophy. London : Bloomsbury, 2013, p. 47. ISBN 978-14411-4214-6.

${ }^{36}$ SUTHERLAND, Thomas - PATSOURA, Elliot. Human-in-the-last-instance? The concept of "man" between Foucault and Laruelle. In Parrhesia, 2015, No. 24, p. 297.

${ }^{37}$ See LARUELLE, François. Anti-Badiou: On the Introduction of Maoism into Philosophy. London : Bloomsbury, 2013. ISBN: 978-1-4411-9574-6.

${ }^{38}$ I accept Laruelle's terminology, where "man" means not "him" or "her", it relies upon both genders.

${ }^{39}$ MARCEL, Gabriel. Being and Having. Westminster : Dacre Press, 1949, p. 21. 
important in theatre) is the frontier district between the life of ordinary man (in philosophy we say "being") and making him "a possession". Even an individual can hardly say that he is "[...] able to dispose of that which gives me the disposal of things," i.e. body. ${ }^{40}$

"The man of whom we speak is his own real identity, the irreductible core which makes him human and does not just differentiate him from the rest of Creation, to which he otherwise belongs [... it is real and not transcendent identity,] the Identity of the One proper to humans and those subjects to which they transmit them via the operation of cloning." 41

I call the mystery the intuition, which Badiou has tried to incarnate in his matheme $\left({ }^{* *}\right)$ (which is not matheme, because it is an unmathematical mise-en-abîme ${ }^{42}$ ) as a testimony of being a living human himself. If we keep it as a symbolic metaphor (which is no prior than an image of poetry), it is possible to sign the mystery as the void - Ø. Its "groundness" is of no "ground" because every knowledge of it is particular (no one being prior). Martin Buber tries to grasp it with his term of Ungrund, which provides a platform for any dialogue possible:

"Now from my own unforgettable experience I know well that there is a state in which the bonds of the personal nature of life seem to have fallen away from us and we experience an undivided unity. [...] I may call this an original pre-biographical unity and suppose that it is hidden unchanged beneath all biographical change, all development and complication of the soul [...] my spirit has no choice but to understand it as the groundless." ${ }^{43}$

This assumption is of no use for defining the mystery (what is impossible). The theses declare that on this ground there is a possibility of transgressing individuality. In every person in flesh and blood, there is something ungrounded, which makes all humanity the One. Man-in-person, as Laruelle says, human in-last-instance, is the horizon of our lived reality, which can not be reached by a debate (decision-making, politics in a narrow sense). We can believe that it is possible to approach this horizon as embodied persons in a dialogue. Therefore, the dialogue is an ultimate truth-procedure, which is not committed to philosophical terms. Where can be the dialogue experienced? In art, where ordinary man creates the testimony of his life, the testimony which can be experienced by other ordinary men solely by their humanity. ${ }^{44}$

As a truth-procedure, I posit art as the subject's encounter with mystery, or more precisely: the subject is produced vis-à-vis the living man's encounter with mystery. Therefore, this subject has to be real, not only abstract as it is in Badiou's "mathemati-

\footnotetext{
${ }^{40}$ Ibid., p. 82.

${ }^{41}$ LARUELLE, François. Future Christ: A Lesson in Heresy. London - New York : Continuum, 2010, p. 23. ISBN 978-1-4411-1833-2.

${ }^{42}$ NIRENBERG, Ricardo L. - NIRENBERG, David. Badiou's Number..., pp. 598 - 599.

${ }^{43}$ BUBER, Martin. Between Man and Man. London - New York : Routledge, 2002, p. 28. ISBN 0-415-27827-9.

${ }^{44}$ The idea that a performance can promote a dialogue is hardly new. See e.g. BRANDT, Willy. The Political Significance of the Theatre. In Comparative Drama, 1973, Vol. 7, No. 3, pp. 222 - 230. Brandt sees dialogue as the characteristic which makes theatre a priori political: "It is the dialog[ue] that enables man to become a zoon politikon. [...] The stage, the adversary of Politics, represents conflict and makes the audience aware of it." Through this representation can a performance contribute to the peaceful solution of conflicts. But this view of the topic is committed to the classical definition of theatre as drama as well. My approach is different.
} 


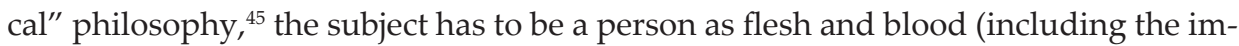
perfection of personality). This is the fundamental advancement of Badiou's theory. The militant is committed not to any truth as an ideology (e.g. the ideology of class), but the truth of the mystery is his sole bond. A mystery is not a problem to solve - it provides no solutions and no debates. It opens a space for dialogue. Mystery requires both commitment and humbleness because it exceeds human scopes. But in its transcendental perspective (sub specie aeternitatis) the mystery announces the ultimate horizon, the transgression of limits and reach of the universality (oneness). This hardly can be any science of revolution (as it is in Marxism). ${ }^{46}$

Badiou's arguments are delusive. They seem to be a celebration of human freedom, but it is just a deceitful phantom. Badiou would like to base the discovery of truth on the scientific (mathematical) ground, but it is rather a fraud. His thought is of force, it "[...] reinstates the Maoist order in conceptual philosophy by a resurrection of dialectical materialism [...]," and it has "[...] nothing but scorn, denial, or at best indifference for democracy and victims." 47 This is the price for the mathematization of ontology, which deprives subjects of their flesh and blood.

However, in theatre, in performance, we can almost (and sometimes literally) touch others, as they are presented to us as bodies, as living persons, actors, and fellow spectators. The event as the revelation of mystery is brimful of life, the event envisaged as a matheme is a true void (not as a multiplicity, but as a total vacuum). ${ }^{48}$

\section{The Event of Performance}

I would like to offer another possible interpretation of "the matheme" of the event $\left.{ }^{*}\right)$. We have seen that it is not only that the event is present in itself $\left(e_{x}\right)$, but also that any event has its position in space and time - its site $(x \in X)$. This thereness of any event, its ubiety, posits the event a) in materiality, b) in time. Moreover, as we know from Erika Fischer-Lichte's aesthetics of performativity, this presentness is an inherent attribute of performance engaging actors as embodied minds. ${ }^{49}$

${ }^{45}$ For Badiou, subject is "[...] any local configuration of a generic procedure from which a truth is supported." BADIOU, Alain. Being and Event..., p. 411.

46 "Badiou seems to promise a renewal of scientific communism, this time built, not upon nineteenth century notions of matter and energy such as those Friedrich Engels had used in his 1883 Dialectics of Nature but on the new physical conceptions, where the quiddity of matter fuses into mathematical structure-nothing less than a Marxian aggiornamento, this time coupled not with Freud but with Lacan. The promise is all the more alluring to those who watch with mounting anxiety as the arts and humanities seem increasingly pushed aside by the expanding power of science." NIRENBERG, Ricardo L. - NIRENBERG, David. Badiou's Number..., p. 612.

${ }^{47}$ LARUELLE, François. Anti-Badiou..., p. 18.

48 "Construction without expression is empty [vide]: this is exactly the mathematical ontology of Alain Badiou, naming the void as multiple (as the basis of an axiomatic), declaring the indifference of truth to the world (the construction of eternal truths) in 'offering to the event' as the grace of nomination (the Great Logic of the Signifier)." ALLIEZ, Eric. Badiou: The Grace of the Universal. In Polygraph, 2005, No. 17, p. 270.

49 " [...] presence represents a phenomenon which cannot be grasped by such a dichotomy as body vs. mind or consciousness. In fact, presence collapses such a dichotomy. When the actor brings forth their body as generic and thus generates presence, they appear as embodied mind. The actor exemplifies that body and mind cannot be separated from each other." FISCHER-LICHTE, Erika. The Transformative Power of Performance: A New Aesthetics. London - New York : Routledge, 2008, pp. 98 - 99. ISBN 978-0-203-89498-9. Presentness is Fischer-Lichte's term, I am to use the notion of ubiety when speaking about the attribute of event. 
It is not possible to reduce any subject that is included in the situation of performance to mere discoursivity. Erika Fischer-Lichte (and other theatre scholars, such as Joachim Fiebach and others) provides a sufficient argumentation for the assumption that the subject is embodied in performance (i.e., the subject is particular, not abstract). Rather than dualism and reductionism, the theatre scholars introduce theories of theatre performance as an embodied experience.

The ubiety of performance as an event has the character of presentness. The small $x$ in the equation $\left(^{*}\right)$ can be understood as an individual, the subject (actor, spectator...), with the big X interpreted as a spaciotemporal site of the performance (including its design by a director, writer etc.). Then we can say, that (Def. 1) a performance generates an event on the ground of its ubiety in spaciotemporal materiality of the performance, producing embodied subjects.

The subjects are not isolated in the situation of performance, as Fischer-Lichte explains..$^{50}$ Her radical concept of presence instructs us that in the situation of performance there are hardly any isolated individualities (subjects) present. The individuals are interconnected on the base of a) perception of other subjects, b) perception of themselves, c) recognition of the situation itself (the materiality of the situation the subject is taking part in). Especially the assumptions b) and c) provide the crucial implications for my argument, meaning that (Def. 2) based on the materiality of the performance situation and the presentness experienced by the subject, they are taking part in the situation and recognizing the situation as such at the same time. This means that for the subjects the raison d'être of the situation ("what does it mean for me as a subject?") is the situation itself - the performance has its use for itself (and therefore it can be productive of truth), there is no prior function instead of its performativity and productivity (i.e. the performance produces subjects).

Structuralism claims, that for any artwork it is necessary to possess the aesthetic function as prior. ${ }^{51}$ We have seen that the embodied subject participates in the situation not only bodily (aesthetics) - the theory of embodied mind transgresses the traditional view of aesthetics. If my Definition 2 is valid, then it affirms that the performance possesses its aesthetic function as prior (meaning prior to other functions, such as social et cetera) and is in accord with the aesthetic functionalism.

But this hardly means, that there is no politics in performance, and the aesthetic function is theatre's sole goal! In theatre history, there were even situations when a performance evidently abolished the politics-aesthetics dichotomy (e.g. James Griffith's Commune or Schlingensief's Two Amerindians Visits...). ${ }^{52}$ However, those situations were quite special. The question is, whether there is anything political inherently present in any situation of performance (even theatrical in a traditional sense

50 “Through the performer's presence, the spectator experiences the performer and himself as embodied mind in a constant process of becoming - he perceives the circulating energy as a transformative and vital energy." Ibid., p. 99.

${ }^{51}$ See MUKǍ̌OVSKÝ, Jan. Aesthetic Function, Norm and Value as Social Facts. In Art in Translation, Vol. 7, No. 2, pp. 282 - 303. For the similar view that the function art is to promote "aesthetics communication", see e.g. NATHAN, Daniel O. The Aesthetic Function of Art. Ithaca : Cornell University Press, 2004. ISBN 978-0-8014-3970-4.

52 "The situations the artist had created and to which they exposed themselves and others were simultaneously aesthetic and political. To separate or oppose the aesthetic form from the political became entirely impossible." FISCHER-LICHTE, Erika. The Transformative Power of Performance ..., p. 171. 
of meaning). The answer is affirmative and I am to present my argument in the next chapter of this article, engaging Fischer-Lichte's term of liveness.

\section{The Utopia as the Political in Theatre}

Every thinking on theatre can easily fail if it can not recognize the elusiveness of performance. Albeit scholars of theatre can focus on particular productions (their design, director, scenographer etc.), the performance as an event is necessarily elusive and intangible. One has to take part in it to experience both the presence and distance, as I have previously shown. Therefore, the performance has the nature of Badiousian event.

Badiou explains: "[t]he existence of an event cannot be proved; it can only be asserted. An event is something that can be said to exist (or rather, to have existed) only insofar as it somehow inspires subjects to wager on its existence." 53 But there is not only one subject involved in the performance. My Definition 1 implies that the event of performance produces several embodied subjects - individualities on the stage or in the audience. They experience a co-presence, and they transgress the borders between them. ${ }^{54}$ This is possible because the situation of the event itself (autopoietically) produces a specific feedback loop ${ }^{55}$, which disturbs the authority of a text or the director's concept and opens a possibility for an experience of togetherness - a community (Def. 3).

However, in Fischer-Lichte's theory of aesthetics, the idea of community is present only in its narrow sense of meaning. She claims that a community occurs in the situation of the specific turn the autopoietic feedback loop takes, for example in a role reversal (e.g. in Viennese actionist Hermann Nitsch's Orgy Mystery Theatre or Schechner's Performance Group). This liminal experience is present even in situations of sports competitions, but Fischer-Lichte argues that a single, unified community of all participants can emerge only barely - because the competitions are based "on an agonal principle" which produces "antagonistic communities". ${ }^{56}$

I would like to employ my previous interpretation of Badiou's theory of event to transgress this narrow approach to community. The co-presence, liveness of performance, means that "[...] no matter whether and how a performance told a story, it is the bodily presence of the actors that affects [the audience] and sets the autopoietic loop in motion." ${ }^{57}$ But if actors and audience are co-presented, they also have to find common ground on which the autopoietic feedback loop can operate. This applies not only to human cognition, but it also requires an employment of a deep ground of human (embodied) mind - the unconscious. Even contemporary neuroaesthetics and cognitive science try to grasp this phenomenon in its concept of resonance (analogous to the feedback loop theory in theatre studies).${ }^{58}$ On this ground, all the humans are

\footnotetext{
${ }^{53}$ BADIOU, Alain. Being and Event..., p. 115.

${ }^{54}$ This approach is clearly distinct from the didactic, romantic or classic stance. It is consistent with Badiou's argument. See again HALLWARD, Peter. Badiou: A Subject to Truth..., p. 194.

${ }^{55}$ FISCHER-LICHTE, Erika. The Transformative Power of Performance..., p. 50.

${ }^{56}$ Ibid., p. 198.

${ }^{57}$ Ibid., p. 74.

${ }^{58}$ See FREEBERG, David - GALLESE, Vittorio. Motion, emotion and empathy in aesthetic experience. In Trends in Cognitive Science, 2007, Vol. 11, No. 5, pp. 197 - 203; or JOUFFLINEAU, Coline - VINCENT, Co-
} 
part of one community (they are able to "resonate" on the unconscious level) and it does not matter if they are present "in reality" (actors, spectators), or only imagined (characters, mythological personalities). This is the horizon of politics - the Utopia.

In politics, ${ }^{59}$ humans aim to construct their future, transforming their present times. Politics not only produces the State, as Alain Badiou claims, but it produces an image of the ideal community (the humanity) as well. This theory of politics is dedicated to aforementioned Graeber's analysis - the states are the complexes of ideals ("utopias") and the forms of institutionalized raiding or extortion for him.

Ernst Bloch elaborated an analogous theory in his book The Principle of Hope, in which he understands utopias as an imaginative endeavors being both critical towards the present state and anticipating future. This "anticipatory" mode operates "[...] in the field of hope; so the hope is not taken only as emotion, [...] but more essentially as a directing act of a cognitive kind [...]." ${ }^{\prime 60}$ Utopias nourish politics, transforming a day-to-day debate on ordinary affairs to the eternal struggle for the ideal - the universal sister- and brotherhood. This means to identify all the particularities as a whole, or, more precisely, to transgress differences and reach an all-inclusive identity, the community.

"The All in the identifying sense is the Absolute of that which people basically want. Thus this identity lies in the dark ground of all waking dreams, hopes, utopias themselves and is also the gold ground on to which the concrete utopias are applied. Every solid daydream intends this double ground as homeland; it is the still unfound, the experienced Not-Yet-Experience in every experience that has previously become." ${ }^{\prime 61}$

Because I employ Foucault's perspective of politics, it is necessary to understand this not only as an effort to build an ideal political body in which everyone can take part. "The All" is the horizon of two humans in love, the goal of marriage, including children, as well. "The All" is the horizon of the wider family, no matter how elusive this idea is. When two humans aim to transgress their differences, this (inherently political) attempt is somehow oriented towards the ultimate ideal of humanity, the community of humans - and in the last instance to the ideal of unity of all humans, animals and things.

To reach any real transformation, humans have to reach the interpersonal (and intercultural) dialogue based on the imaginative mode of existence, on the shared roots of human existence and their memory. This unconscious platform I call homeland.

ralie-BARCHRACH, Asaf. Synchronization, Attention and Transformation: Multidimensional Exploration of the Aesthetic Experience of Contemporary Dance Spectators. In Behavioral Sciences, 2018, Vol. 8, No. 2, p. 24; or KONVALINKA, Ivana - XYGALATAS, Dimitris - BULBULIA, Joseph et al. Synchronized arousal between performers and related spectators in a fire-walking ritual. In Proceedings of the National Academy of Sciences of the United States of America, 2011, Vol. 108, No. 20, pp. $8514-8519$.

${ }^{59}$ I would like to remind that I am employing the term "politics" in its wider sense of meaning. By politics, I mean everyday interactions on which the power of sovereign is based. In this chapter, I suppose that if these interactions are conscious, they are aimed to transgress a present state to an ideal. In common language, it is "the struggle for better life and/or world". The horizon of this ideal is for everyone to be involved in a common life of a community.

${ }^{60} \mathrm{BLOCH}$, Ernst. The Principle of Hope: Volume One. Cambridge : The MIT Press, 1996, p. 12. ISBN 0-26252199-7.

${ }^{61}$ Ibid., p. 316. 


\section{Neurophysiology and Analytical Psychology of Homeland}

The term homeland may be poetical, but it is a metaphor adequate to reality more than it appears. Even though its research is at its outset, science provides enough evidence - in the fields of neuroscience, cognitive and behavioral science, neuroaesthetics and psychotherapy.

In neuroscience, the ability of the human mind to "share" and "connect" with others is an object of vivid interest. In 1990s, neuroscientist Giacomo Rizzolatti with his colleagues discovered mirror neurons. They were studying macaca mulatta (rhesus monkey) and learned that "ventral promotor and rostral inferior parietal neurons fire when the animal performs hand and mouth actions, but also when the animal is simply observing another individual performing the same actions." 62 The mirror neurons (MN) are also present in the human brain (inferior frontal cortex and superior parietal lobe). There are two kinds of mirror neurons - strictly congruent $\mathrm{MN}(1 / 3$ of all $\mathrm{MN}$, they fire for exactly the same action) and broadly congruent $\mathrm{MN}$ $\left(2 / 3\right.$ of all $\mathrm{MN}$, they fire for actions logically related or achieving the same goal). ${ }^{63}$ The broadly congruent MN present a larger group of cells than the strictly congruent $\mathrm{MN}$, implying that mirror neurons do not concern only the mirroring actions of other individuals, but that they are content- and context-oriented and they help a social interaction.

The mirror neuron system (MNS) is even more active during complementary activity than in the case of mere imitation. ${ }^{64}$ If we can explain the feedback loop between actors and spectators (even just partly) as an expression of the MNS activity, it is evincible to claim that this feedback has its social implications. The mirror neurons areas "implement a simulation-based form of understanding other people's mental states." Several fMRI studies provide the evidence that mirror neurons make it possible to "put ourselves in other people's shoes." ${ }^{65}$ People with higher empathy have more active MNS. ${ }^{66}$ Therefore it is plausible to claim that the feedback loop can synchronize the participants and build a common platform - which I call homeland. ${ }^{67}$

The communication research provides other evidence of brain-to-brain synchronization between individuals. Uri Hasson's research shows that the brains of people speaking different languages are performing similar activities when they are exposed to the same story. The content of narrative is more important than a form (language), and thus the neural responses are insensitive to the language in which the story is

${ }^{62}$ IACOBONI, Marco - MAZZIOTTA, John C. Mirror Neuron System: Basic Findings and Clinical Applications. In Annals of Neurology, 2007, Vol. 62, No. 3, p. 213.

${ }^{63}$ Ibid., p. 214.

${ }^{64}$ NEWMAN-NORLUND, RD - SCHIE VAN, HT - ZUIJLEN VAN, AM - BEKKERING, H. The Mirror Neuron System Is More Active During Complementary Compared With Imitative Action. In Nature Neuroscience, 2007, No. 10, pp. $817-818$.

${ }^{65}$ IACOBONI, Marco - MAZZIOTTA, John C. Mirror Neuron System... , p. 215.

${ }^{66}$ GAZZOLA, Valeria - AZIZ-ZADEH, Lisa - KEYSERS, Christian. Empathy and the Somatotopic Auditory Mirror System in Humans. In Current Biology, 2006, Vol. 16, No. 18, pp. 1824 - 1829.

${ }^{67}$ See e.g. BAO, Yan - PÖPPEL, Ernst - WANG, Lingyan et al. Synchronization as a Biological, Psychological and Social Mechanism to Create Common Time: A Theoretical Frame and a Single Case Study. In PsyCh Journal, 2015, Vol. 4, No. 4, pp. $243-254$. 
told. ${ }^{68}$ The synchronization across persons has its political implications - it predicts mutual prosociality. ${ }^{69}$

The homeland can transgress frontiers of species ${ }^{70}$ and can even step out from the biological kingdom Animalia. ${ }^{71}$ Based on homologies, individuals and biological species can resonate with each other not only emotionally, but also on lower physiological levels.

From the perspective of analytical psychology, the homeland is placed in the unconscious. The homeland is a deep structure - a shared place where collective archetypes are situated. I am referring to Jung's psychology ${ }^{72}$, but his findings are confirmed by the biological research:

"[The evolutionary psychology and psychiatry] confirm that human experience and human behaviour are complex products on environmental and hereditary forces. The environment activates the archetype which mediates the experience and the behaviour. Archetypes are intermediate between genes and experience: they are the organizing schemata by which the innate becomes personal."73

We have to employ our imagination to deal with archetypes which are bodily, not discoursive. Therefore, it is necessary to transgress the limitations of contemporary Jungian position, which is disembodied "as if the physiological correlates of psychic events were of little or no account." 74

A daydreaming human takes part in the homeland bodily. Laying aside all of his or her cultural and individual specifics, he touches a generic soil. This shared, collective experience can be understood as Paul Gilbert's "mentalities," Russell Gardner's "master programmes," or Brant Wenegrat's "genetically transmitted response strategies". ${ }^{75}$ The aforementioned scientists - biologists ${ }^{76}$ provide laboratory records of the deep structure's existence.

\section{The Utopia and Its Presence in Theatre History}

The horizon of the Utopia is not a mere Novum (i.e. transgressing the repetition of hic et nunc), but the Ultimum (the repetition ends). Ernst Bloch explains:

\footnotetext{
${ }^{68}$ HONEY, Christopher J. - THOMPSON, Christopher R. - LERNER, Yulia \& HASSON, Uri. Not Lost in Translation: Neural Responses Shared Across Languages. In The Journal of Neuroscience, 2012, Vol. 32, No. 44, pp. $15277-15283$.

${ }^{69} \mathrm{HU}, \mathrm{Yi}-\mathrm{HU}$, Yinying - LI, Xianchun - PAN, Yafeng \& CHENG, Xiaojun. Brain-to-brain Synchronization Across Two Persons Predicts Mutual Prosociality. In Social Cognitive and Affective Neuroscience, 2017, Vol. 12, No. 12, pp. $1835-1844$.

${ }^{70}$ MANTINI, Dante - HASSON, Uri - BETTI, Viviana - PERRUCCI, Mauro G - ROMANI, Gian Luca - CORBETTA, Maurizio - ORBAN, Guy A \& VANDUFFEL, Wim. Interspecies Activity Correlations Reveal Functional Correspondence Between Monkey and Human Brain Areas. In Nature Methods, 2012, Vol. 9, No. 3, pp. $277-282$.

${ }^{71}$ HUSS, Ephrat - YOSEF, Kfir Bar - ZACCAI, Michele. Humans' Relationship to Flowers as an Example of the Multiple Components of Embodied Aesthetics. In Behavioral Sciences, 2018, Vol. 8, No. 3, p. 32.

72 JUNG, C. G. The Archetypes and the Collective Unconscious. Princeton : Princeton University Press, 1980. ISBN 0-691-09761-5.

${ }^{73}$ STEVENS, Anthony. Archetype Revisited: An Updated Natural History of the Self. London : Brunner-Routledge, 2002, p. xii. ISBN 0-203-62712-1.

${ }^{74}$ Ibid., p. 55

${ }^{75}$ Ibid., p. 53.

${ }^{76}$ And many others, see the book by Anthony Stevens cited for an overview.
} 
"[The repetition] only ends by virtue of the fact that, to the same extent that the Ultimum represents the last, i.e. the highest newness, the repetition (the unremitting representedness of the tendency-goal in all professively New) intensifies to the last, highest, most fundamental repetition: of identity. And the newness in the Ultimum really triumphs by means of its total leap out of everything that previously existed, but it is a leap towards the newness that is ending or identity."77

Historically, in human societies and in particular human individualities, all subjects were limited to their hic et nunc identity. The homeland transgresses these limitations because it possesses no form. There we can enjoy the common, what we share, anticipating the ultimate state in which there will be no "others", no borders, no differences. This ultimate state is a generic multiplicity, free as an imagination, the Utopia. As the Ungrund, it can be symbolically marked as $\varnothing$, because it is nongrounding (unconscious) groundness, multiplicity producing particular elements. It is the unconscious archetypal universum which takes a form of myths or symbols in our particular historical cultural and individual consciousness. In psychotherapy, several researches imply that creative arts therapies not only tranquilise homesickness, but they also integrate culturally diverse individuals. ${ }^{78}$

During performances, actors and spectators are bodily experiencing the ungroundness as a part of the liveness (Def. 4). It hardly depends on a genre, or particular form, or topic. Being a product of collective imagination, realised bodily and experienced according to the shared aesthetical mode, the performances are situations, where through the liveness the homeland is not only imagined but lived.

We have to admit that this immersion to the common ground has its degrees the lowest is present in national and bourgeois theatres which are producing only very limited community of admirers. But what all the humans experience during any performance is the possibility of ultimate collectivity, of transgressing all of the individualities, because we are all humans sharing the same existential ground. This is what I call the Utopia. (Def. 5)

What is the Utopia like? It is where all human (and even non-human, as we have seen) grounding is placed. Through imagination, spectators recognize performers and each other as humans, because they are able to understand their experience (even if they do not accept it), it is mirrored in themselves (and vice versa). It is possible to adopt a concept of structural homologies from biology: in our lives we are experiencing homologous situations, producing shareable emotions and reaching universally human existential questions (even if the answers are not universal, but cultural). Humans are mortal beings (such as all animals and plants are) dealing at least with their mortality (these are arguments for the Definition 4). And this also is the Utopia - which is fragile, mortal, but ultimate and hopeful at once.

Because humans are able to dwell in this place only in their (embodied) imagination, it is a non-place, the Ungrund - the groundness, which is no ground. Unlike our homes (cultures, local myths, limited collective memory) it possesses no particular forms, it is not present in our consciousness, rather it is unconscious and shapeless. It can reach a form only in the case of particular artwork, which employs historically

${ }^{77}$ BLOCH, Ernst. The Principle of Hope ..., pp. $202-203$.

${ }^{78}$ DIETRICH-HARTWELL, Rebekka - KOCH, Sabine C. Creative Arts Therapies as Temporary Home for Refugees: Insights from Literature and Practice. In Behavioral Sciences, 2018, Vol. 7, No. 4, p. 69. 
and the culturally specific symbolic universe. But as the ground it is ungrounded, continually changing rhizomatic memory of our phylogenetic experience.

We can convincingly trace the effects of this Utopia in the history of European theatre. That is so because the utopian community is not determined by a specific ideology of state or by the existence of national state at all.

The Greeks were aware of this power of theatre when they provided every Athenian the right to participate "[...] actively or act as a spectator at the festival in honour of Dionysus."79 And for the same reason a theorikon ("spectator's wage") was paid to every spectator. These performances were producing crowds involved in a discoursive practice, as Alain Badiou claims. But this was an effect of the vivid utopian experience of community (transforming a subject-object dichotomy to ungrounded togetherness, if it was even just for the time of the performance).$^{80}$

The Utopia was present in the medieval practice of performing vernacular plays in church courtyards or town market squares. The religious dimension of the Utopia is underlined by the fact that these performances developed from "Latin celebrations in the church". ${ }^{81}$ During these events, it was not only the collectivity of polis what was produced, but of Christianity in general - meaning that everyone (no matter of their ethnic grounds) who took part in the Christian revelation, was recognized as a brother or sister.

And it was the very same Utopia which supported the self-awareness of bourgeoisie in the $18^{\text {th }}$ century's German theatre. The newly established middle-class enjoyed performances as a daily event of their public life with their vivid interventions during the shows (applause and condemnation during the play, promoting morals and order in the theatre). These interventions are an evidence that the situation of the performance was not only fully immersive but that it also sustained a functional distance of the audience. As I have shown before, it means that the event was included in itself $\left({ }^{*}\right)$. The illusion of acting was accompanied by the audience's awareness of the performance itself (producing theatre criticism). This is observable before the founding of the Hamburg National Theatre in 1767, which "[...] was programmatic of the new demand that should be the forum of bourgeois life." ${ }^{2}$

As Erika Fischer-Lichte shows in her book Theatre, Sacrifice, Ritual, it is possible to trace evolution of "political theatre" in $20^{\text {th }}$ century, such as the mass spectacles shaping and establishing "a lasting collective identity". ${ }^{83}$ This re-invention of a ritual was a symptom of the transgression from "textual" to "performative" culture, as FischerLichte argues. But my definition of the Utopia is independent of the accent on text or

${ }^{79}$ FISCHER-LICHTE, Erika. History of European Drama and Theatre. London - New York : Routledge, 2002, p. 9. ISBN 0-415-18060-0.

${ }^{80}$ Erika Fischer-Lichte explains that "Greek theatre merely reaffirmed and renewed the existing community of polis, which was already confirmed through the processions, sacrifices and various other acts of national self-representation. Theatre arose out of this political community." FISCHER-LICHTE, Erika. The Transformative Power of Performance ..., p. 56. But it hardly means that the theatre did not produce a community. The author only reminds us, that this community was not transgressing the boundaries of a Greek city. But it does not imply, that there was present no imaginative anticipation of the transgressing at all. We can assume that the lower degree of the Utopia was experienced.

${ }^{81}$ FISCHER-LICHTE, Erika. History of European Drama and Theatre..., p. 34.

${ }^{82}$ Ibid., p. 151.

${ }^{83}$ FISCHER-LICHTE, Erika. Theatre, Sacrifice, Ritual. London - New York : Routledge, 2005, p. 96. ISBN 0-415-27676-4. 
its absence. The liminality which is present in more "ritual" performances is a revelation of the Ungrund on another level. All that Greek, medieval, bourgeois and avantgarde performances are similar situations revealing Utopia, but sometimes (such it was in Ancient times or the era of the rising national consciousness) producing very limited communities.

Of course, all these examples from the theatre history are evidence of a very limited immersion into the Utopia. And that is understandable - this homeland of the Utopia is both hopeful and anticipating (Ernst Bloch), but also non-reachable. It is still ou-topos, a non-place, the site which we experience in our inner selves. To reach it in our daily lives is the matter of (real) politics.

\section{Conclusion}

This article should be understood as a cross-disciplinary endeavour. It employs some parts of theatre theory to rethink Alain Badiou's concept of theatre-politics isomorphism. To be able to approach this goal means to reformulate Badiousian ontology. I would like to remind that this operation was possible on the ground of uncoupling Badiou's ontology from mathematics.

My argument is simple. I assume that the void $(\varnothing)$ in Badiousian sense of meaning can be understood as unconscious phylo- and ontogenetic memory of humans. To be on the edge of it means that a person is experiencing an event, the situation transgressing its own finite determination and reaching the multiplicity. This transgression is possible because the subject produced by the event is called not only by the situation but the event itself - the subject asserts it $\left({ }^{*}\right)$. And this recognition of the event goes hand in hand with the openness and freedom of the multiplicity $(\varnothing)$, which is at the same time grounding this experience.

For me, this "ungrounding grounding" (Buber's Ungrund) has the character of mystery. The specific distance is necessary to recognize the situation as an event $\left(^{*}\right)$. Humans both are and are not part of it. And it is the same with the unconscious character of this grounding. It is the clear possibility, absolute freedom, but at the same time the structural homology is engaged on this level. We are able to reach the phylogenetic (archetypal) memory not only of our species but of the life on Earth itself. On this homologous basis, we are able to transgress the limits. ${ }^{84}$ We recognize the limits of ourselves (and the ultimate limit - death), and therefore we can understand the limits of others. In this imaginative space, this homeland of humanity, we are able to understand ourselves as a part of the community. This community is the community of living creatures, which are all connected by their fate of mortality and knitted by the resonance (feedback loop).

I have presented five definitions, which are to be a starting point for a reformulation of Alain Badiou's theory of theatre. They are not definitions in the sense of the end of a discussion. Instead, they are designed to be provocations, which should fuel the debate. I have tried to show that for this endeavour it is productive to employ the

\footnotetext{
${ }^{84}$ I have not discussed the essential condition of it, the empathy: "If one wishes to emphasize commonality, the easiest way is to point out that they [the other group] also feel pain." GRAEBER, David. Fragments of an Anarchist Anthropology ..., p. 75.
} 
theory of Erika Fischer-Lichte - and I have also made some critical remarks on it. Let this be the starting point as well.

To conclude, I would like to sum up my definitions in this theoretical assumption: Any performance generates an event on the ground of its ubiety in spaciotemporal materiality of the performance, producing embodied subjects. This situation generates the autopoietic feedback loop, which disturbs the authority of a text or the director's concept and opens a possibility for an experience of togetherness - a community. This community is imagined on the basis of unconscious ungroundness. The actors and spectators are experiencing this ungroundness bodily as a part of the liveness of performance. The possibility of ultimate collectivity, of transgressing all of the individualities, as we all are humans sharing the same existential ground, is the Utopia. And because every utopia has its critical (towards the present state of affairs) and anticipatory dimensions (Ernst Bloch), this experience is analogous to any political prospection.

Translated by the author, edited by Klára Škrobánková

\author{
Jan Motal \\ Divadelní fakulta Janáčkovy akademie múzických umění \\ Mozartova 1 \\ 66215 Brno \\ Czech Republic \\ E-mail: motal@jamu.cz
}

